\title{
PARA UM IMANENTISMO ABERTO (O REDUCIONISMO SOLIPSISTA)
}

\author{
JosÉ Augusto MOURÃo*
}

\section{RESUMO}

A revolução galilaica era a "boa explicação». O reducionismo como método único e explicação única dos fenómenos parece ter entrado em crise. A situação actual da ciência implica uma multiplicidade de propostas de explicação. A linguística primeiro, a semiótica depois, cederam durante décadas ao desejo de um imanentismo metodológico, desenvolvendo representações arborescentes, nominalistas, do sentido. A hipótese localista de J. Petitot propõe sair deste solipsismo metodológico, reconhecendo que há entre o mundo real e a estrutura conceptual uma relação interactiva. Discutem-se aqui os limites do reducionismo fechado (solipsista), propondo-se um imanentismo aberto, via fenomenologia e ciências cognitivas.

There is an obvious advantage in being able to explain complex things in terms of simpler ones, or large systems in terms of smaller. Therefore analysis, with its reduction from complexity to simplicity, is tradicionally a useful way of doing science. However, its drawbacks become apparent when analysis adopts the position "nothing but». When chemistry is "nothing but the physics of molecules», an organism is "nothing but its constituent chemistry," and mind "nothing but nerve cells and neurochemicals in action, "then a narrowness of perspective results.

F. DAVID PEaT

On peut parler avec raison de l'arbitraire des descriptions, ne serait-ce que parce qu'on est obligé d'introduire la possibilité des lectures, non pas plurielles, mais de plusieurs lectures d'un discours.

A. J. Greimas

* Professor do Departamento de Ciências da Comunicação da Universidade Nova de Lisboa. E-mail: jam@mail.telepac.pt 
O que caracteriza o discurso da sedução, em oposição ao discurso do método, é o ser ele incontornável, irrepetível e recuperável. Nos anos setenta premuniam-nos contra os Incontroláveis. Eles aí estão de volta, que opõem o saber à cultura, essa velha manobra do obscurantismo, desfiando as misérias da poética formal, da semiótica ou do desconstrucionismo, presumíveis responsáveis, entre outros desastres, pela desertificação das «letras» no canto ocidental ou outro. Epígonos dessa operação não faltam. A sedução da curva, dos meios líquidos, do mote "variável», acompanha a obra magnífica de M. Serres, um epistemólogo-poeta que, como nuvem, de desapego em desapego, se vai aproximando de Heraclito, Diógenes ou S. Francisco 1. Percurso este sem dúvida incontornável, irrepetível e recuperável. Com efeito, esta mesma sedução parece contagiar aqueles que, sem o engenho e o saber do epistemólogo-poeta, se ocupam da «coisa literária», fascinados pelo seu inefável, sob o chapéu da nebulosa místicoesotérica da contemporaneidade que tudo mistura, tudo dissemina, tudo confunde. Como se víssemos a linguagem, e um êxtase branco nos impedisse de a indexar ao seu material significante, à sua aptidão para se referir ao mundo e a co-enunciadores em relação.

Apresentar uma série interminável de autores é seduzir a partir de múltiplos deuses errantes, despolarizados, ceder a uma perspectiva analítica, desviante em relação a um cartesianismo original, renunciando ao princípio de empirismo. Mas é essa a sina do pós-moderno. Confrontamonos com o regresso da intuição, esse cálculo, essa apreensão global e imediata de um fenómeno. Com o regresso do sujeito avaliador, perceptivo assistimos também ao regresso da sensibilidade e da sereia estética ${ }^{2}$. Regresso do cognitivo, não apenas sob as espécies do saber, mas da crença, do modal (patémico), do estético (eficácia simbólica) e do fenomenológico. Afirma-se que entrou em falência todo o modelo científico de previsão/ explicação dos textos; que o estruturalismo decaiu quando se tornou generalização de certo tipo de procedimentos. Renunciou-se mesmo, nos estudos literários, a este tipo de perguntas: qual o nível de organização duma estrutura? Quais os critérios de individuação do objecto texto? Deixou-se mesmo de questionar o texto como «um artíficio sintáctico-semântico-pragmático cuja interpretação prevista faz parte do seu próprio projecto generativo" ${ }^{3}$, artifício que, por ser artifício, obriga a discernir o elementar

1 François Lyotard sugere a mesma metáfora da nuvem para indicar a "movência» de todo o pensamento e de toda a abordagem dos objectos na sua última obra, Péregrinations, Paris, Galilée, 1990.

2 Vd Herman Parret, A estética da comunicaçāo. Além da Pragmática, Editora da UNICAMP, Campinas, 1997.

3 Cf. U. Eco, Leitura do texto literário. Lector in fabula, Lisboa, Presença, 1983. 
da sua composição, o seu tecido e o seu efeito. Chegou o tempo de ajustamentos, reequilíbrios, recentramentos. $O$ fantasma da unidade das ciências, a bandeira da interdisciplinaridade estão aí a assinalar o regresso do recalcado. Mas há perguntas que não podemos evitar: pode a interpretação conhecer limites, ser partilhável, pública? Pode a ciência renunciar ao formalismo da descrição? E não é a paranóia da interpretação a mesma que corrói o ocultismo, a mesma em que o gnóstico é o único a poder restabelecer a pureza do mundo, por um lado, e em que, por outro, o texto se converte em lugar de silêncio ou em continente negro?

\section{O método}

Que é o "método»? Vejamos rapidamente o que por ele se tem entendido ao longo da história da ciência. $O$ dicionário fornece-nos uma série de palavras-chave que permitem delimitar o conceito: descobrir, demonstrar, ordem, arranjo, via, escopo em função de um conteúdo a procurar: a verdade. $\mathrm{O}$ método é a «dialéctica» intuição/dedução, como um movimento do mais geral para o mais particular, associado a uma arte, via ou ratio, sendo Boécio o primeiro a empregar a palavra methodus num sentido filosófico. Em Platão, a palavra methodos designa uma pesquisa reflectida, dialéctica: «O método dialéctico (he dialektike methodos) é o único que, ao rejeitar sucessivamente as hipóteses, se alça ao princípio mesmo para assegurar solidamente as suas conclusões» 4 . A primeira frase da Etica a Nicómaco de Aristóteles esclarece o pensamento do filósofo sobre o método: "Qualquer arte (tekhne) e qualquer disciplina científica (methodos) - e o mesmo se diga da acção (praxis) e da intenção moral (proairesis) tendem para um certo bem» $(I, 1)^{5}$. A palavra tem geralmente em Aristóteles o sentido de "pesquisa» (Física III, 1200 b/3). Por vezes também o sentido de disciplina ou de procedimento (Meteoros I, 1338 a e 339 a). Também H. Bonitz, no seu Index aristotelicus, indica como primeiro sentido de methodos "via ac ratio inquirendi» e como segundo «disputatio ac disquisitio", com um sentido próximo de techne ou de episteme.

No começo do Renascimento, o termo methodus é sinónimo de arte, mas tem já um sentido novo: "o método permite igualmente facilitar e acelarar a aquisição e o domínio de uma arte.» Ph. Desan resume este conceito assim: «O método é, pois, uma maneira de pensar, um meio de

4 Ver Republica 533 c. Cf. L. Meridier, «Le mot methodos chez Platon», Revue des Etudes Grecques 22, 1909, pp. 234-240.

5 Cf. Trad. R.A. Gauthier e J.Y. Jolif, Louvain, 1959. 
organizar e de compreender o mundo que nos rodeia, a partir de um percurso que se quer «teórico». A sua finalidade é a «verdade»» 6 .

\section{A suspeita}

É bem conhecida a «cólera» de Péguy contra o «método científico moderno" 7, cólera que, ainda assim, anda muito longe da sanha de Torga contra o estruturalismo, em nome da inspiração ou da reivindicação da relação intensa, total, com os «textos» 8 . A "cólera» de Peguy contra o método científico de tipo lansoniano é uma reivindicação da relação com os «textos», antes de mais. Vale a pena lembrar os motivos da sua "cólera»:

"...o método moderno resume-se nisto: dada uma obra ou um texto, como é que o conhecemos? comecemos por não ligar ao texto; livremo-nos de pôr as mãos nele e de nele pormos os olhos." (Zangwill, Cahiers de la quinzaine).

A suspeita erigida em método levou a geração do pós-guerra a ver na ciência exclusivamente um instrumento de dominação. Por seu lado, a sociologia da ciência não deixou de denunciar o papel determinante da luta pelo poder e o peso que têm na investigação os factores institucionais. Thomas S. Kuhn ( $A$ estrutura das revoluções científicas) e James Watson (A Dupla Hélice) muito contribuiram para propagar tal imagem da ciência. Acrescente-se a estes dois autores o cartógrafo da relação saber-poder da ciência e da sua história que é Paul Feyerabend 9 . É contra os racionalistas e outros adeptos da epistemologia de K. Popper, que Feyerabend escreve estes livros-manifestos. É preciso dizer adeus às falsas explicações e à ideia da eficácia da ciência e sobretudo à sua pretensão de sucesso «universal» 10 . Pode reagir-se dizendo que os métodos pertencem à ciência e que são o lugar de teste da verdade. Mas em arte a questão, v.g. a questão da verdade, não se põe, logo os métodos não lhe dizem respeito. A mesma acusação, afinal, provinciana, de alguns escritores contra a Teoria da Literatura,

6 Philippe Desan, Naissance de la méthode, Paris, Nizet, 1987, p. 9; sobre o espírito crítico "erudito" durante a segunda metade do século XVI, ver Jean Jehasse, La Renaissance de la Critique. L'essor de l'Humanisme érudit de 1560 à 1614, Saint-Etienne, Publicações da Universidade de Saint-Etienne, 1976.

7 Ver Jean-Michel Rey, Colère de Peguy, Paris, Hachette,1987.

8 Cf. Miguel Torga, Diário XIV, Coimbra, 1987, p. 149.

9 Cf. Contre la méthode, esquisse $d$ 'une theorie anarchiste de la connaissance, Paris, Seuil, 1979 e Adieu la Raison, Paris, Seuil, 1989.

10 Sobre a relação ciência e filosofia, ver os debates R. Thom, A. Abragam, P. Jacob e outros em A Filosofia das Ciências Hoje, coor. de J. Hamburger, Lisboa, Fragmentos, 1988. 
considerada responsável pela desertificação da criação literária entre nós ${ }^{11}$. O mesmo fantasma do continuum que transgrida o limite da diferença discursiva - o princípio do "potlach» linguístico. Porém, não há método que não parta de uma cosmologia e de uma prática discursiva própria a dada época. Cada geração tem a sua leitura das obras do passado. Errado seria considerar que esta leitura é superior às precedentes, mas não podemos dar-nos uma alma de contemporâneos de Sófocles ou de Tomé de Jesus 12. Lemos as obras do passado à maneira da nossa época. Há alterações que defluem da distância que nos separa do objecto; da proximidade da nossa própria história; das grelhas de leitura, que não são neutras. De resto, nem Tomé de Jesus compõe a sua obra sem o prévio conhecimento de outras «artes de rezar». Erasmo redige um método para o estudo da teologia, Ratio seu methodus comendio perveniendi ad veram theologiam (1516); não faltam no seu tempo inúmeras "artes de rezar».

Apesar das profissões de fé contra o método ou contra as pretensões totalitárias da teoria (Lyotard e Fish), não se pode ceder à fragmentação, que se tornou o princípio estético e metodológico tanto dos pós-estruturalistas (pense-se em Foucault: 1984: 15), como da Escola de Francforte (Adorno, 1984: 171). É certo que nenhuma disciplina, nem mesmo nenhuma inter-disciplina pode abarcar o exame da significação - este é um dado aceite. Não será necessário sair da lógica compreensiva para renunciar a exprimir a parte pelo todo? As aporias fundadoras de cada ciência estão sempre ligadas a considerações de ordem genérica, do tipo unidade e diversidade, local e global, caos e cosmos, reducionismo e holismo. Será empresa desesperada a que visa o conhecimento do todo a partir da parte? Não haverá uma parte que só seja parte? Uma ciência só existe quando se pode proibir coisas. $O$ acto de conhecimento é solidário de um acto de ignorância - é esse o lado demoníaco do conhecimento, fundamentalmente imperfeito.

\section{Reducionismo e linguística}

A linguística tem por finalidade explícita descrever a língua «nela mesma e por si mesma», desde Saussure, o que significa que ela deve excluir do seu campo teórico as considerações que excedam a estrita observação dos significantes verbais - é esse o princípio que funda aquilo a que se chama «o imanentismo radical». Mas um imanentismo assim corre o

11 Ver "Inquérito: Teoria da Literatura e Ficção" in Colóquio/Letras, n. 64 , Novembro de 1981, pp. 5-9.

12 José Augusto Mourão, Sujeito, Paixão e Discurso. Trabalhos de Jesus, Lisboa, Vega 1996. 
risco de ser hoje mais paralisante do que produtivo ${ }^{13}$. Kerbrat-Orecchioni propõe um "imanentismo aberto», que consiste em admitir que é legítimo dar um lugar, no interior da teoria linguística, a determinadas considerações julgadas precedentemente «extravagantes» e que respeitam às condições de produção/recepção da mensagem, bem como a natureza particular do enunciador, do enunciatário e da situação de enunciação ${ }^{14}$.

A representação do sentido pode fazer-se, segundo J.C. Anscombre, de duas maneiras, em princípio radicalmente opostas. Falo da atitude de simulação (dita também formalizante) e da atitude reducionista. $\mathrm{O}$ método de simulação consiste em explicar um conjunto $\mathrm{X}$ de fenómenos construindo um determinado mecanismo $M^{\prime}$ cujo conjunto $X^{\prime}$ das produções é julgada análoga a $\mathrm{X}$. Põe-se então a hipótese que, na «natureza», $\mathrm{X}$ é o produto dum mecanismo $\mathbf{M}$ análogo a $\mathbf{M}^{\prime}$. Assim no século XVII, a biologia nasceu por um método de redução, a partir da ideia cartesiana do animal-máquina. Donde a voga extraordinária que deviam conhecer os autómatos. Do lado contrário, a concepção de aviões é uma atitude tipicamente de simulação: não se propõe imitar o voo dos pássaros, mas chegar a voar na base das leis da aerodinâmica. Na prática, as duas atitudes não são assim tão distantes. A atitude reducionista pode fazer apelo a um conjunto reduzido de fenómenos naturais estudados através de um método de simulação. A atitude reducionista tinge-se de simulação. Inversamente, acontece que a atitude de simulação acabe por confundir os mecanismos $\mathbf{M}$ e $\mathbf{M}^{\prime}$. Deslisa-se então para uma atitude reducionista. A primeira versão da gramática generativa tentou determinar a época de aparição de determinadas transformações na criança. Em semântica linguística, o método de simulação consiste em forjar uma metalinguagem (geralmente lógica) que permite estudar os fenómenos de sentido não já directamente, mas através de uma estrutura profunda. A teoria da argumentação na língua (Ducrot/Ascombre) assenta tipicamente numa atitude de simulação ${ }^{15}$.

Em resumo, há duas hipóteses possíveis:

(R1) Estudo dos fenómenos de sentido através de um método reducionista.

(R2) estudo dos fenómenos de sentido através de um método de simulação.

13 C. Kerbrat-Orecchioni, L'énonciation, Paris, A.Colin, 1997, p. 220.

14 Jean-Pierre Esquenazi, «Éléments pour une sémiotique pregmatique: la situation, comme lieu du sens», Langage et société, n. ${ }^{\circ} 80$ - Junho 1997, pp. 5-38.

15 J.-C. Anscombre, "Regards sur la sémantique française contemporaine», Langages Mars 1998, 129, pp. 43-44. 
O projecto saussurreano, que considera a língua como uma estrutura em si e a estudar em si mesma faz apelo a hipóteses do tipo de (R2). G. Guillaume é também um dos primeiros a utilizar estas hipóteses em semântica, mesmo se eivadas de reducionismo, na medida em que a sua psicomecânica é psycho. Os linguistas que vêm o funcionamento semântico decorrer directamente do funcionamento neuropsicológico humano inclinam-se para a atitude (R1). É a abordagem específica das ciências cognitivas. (R2) é a atitude mais própria às tentativas de formalização.

Anscombre vê dois tipos de reducionismo:

(R3) Redução da semântica a uma disciplina não-linguística.

(R4) Redução da semântica a uma disciplina linguística outra.

Um exemplo de (R3) consiste em ver os fundamentos da semântica em disciplinas como a teoria da informação, a psicologia, a sociologia, etc. É o que faz Bourdieu em Ce que parler veut dire quando critica Austin de tratar a performatividade como um fenómeno linguístico. A existência desta performatividade deve-se «às condições sociais de produção e de reprodução entre as classes do conhecimento e de reconhecimento da língua legítima..." (p. 113). Em relação a (R4): a atitude do esquema tripartido de C. W. Morris que faz derivar a semântica da sintaxe. O sentido dum enunciado é apenas a interpretação da sua estrutura sintáctica. Uma frase ou uma palavra são definidas por um conjunto de transformações parafrásticas sintácticas e morfológicas ${ }^{16}$. Entre os defensores de uma semântica autónoma (R2) há uma corrente que trabalha com noções a que habitualmente se chamam mundos, universos ou espaços. A Teoria dos mundos possiveis, de D. K. Lewis (1968) parte da ideia de inventar uma lógica modal sem operadores modais, os quais (como Possível e Necessário) colocam problemas difíceis (de extensionalidade).

\section{Formalidade e imanência}

Algo estará a mudar na epistemologia das ciências: não é a linguagem (o discurso) que cria o objecto - como pretendia Saussure e toda a tradição imanentista -, mas é a ordem do mundo, o real radical que transforma a linguagem. F. Laruelle escreve: «Não intervimos no real, mas na lin-

16 Vd D. Leeman, "Le 'sens' et l'information' chez Harris», Linx, 1996, n. ${ }^{\circ}$ especial, Paris X, pp. 209-220. 
guagem» 17. Aqueles a quem este autor chama os não-filósofos (os científicos) mudam a ordem dos seus pensamentos em função da ordem do mundo, e não o contrário. Ir do homem à ciência, e não o contrário, sem ceder um milímetro ao criticismo, e em nome da imanência radical do $U m$, o místico; liquidar o idealismo espontâneo que acredita que é a ciência que determina o seu objecto. Estamos bem longe do imanentismo defendido pelos linguistas. Através de uma série de distinções metodológicas (língua/fala, sincronia/diacronia, sintagma/paradigma, etc.), Saussure define a língua como «um sistema de signos que apenas conhece a sua própria ordem» 18. Como qualquer sistema, a língua, que é um sistema fortemente hierarquizado, não se ocupa dos termos em si mesmos, quer seja o som ou o sentido de uma palavra isolada, só das relações entre os termos. A língua assim definida é forma, isto é, malha de relações, e não substância: «na língua não há senão diferenças» 19.

A realidade pode tornar-se uma questão puramente metalinguística se ela é definida em termos de lógica da linguagem. O nominalismo actual alimenta-se da relação em espelho entre os acontecimentos e os discursos que tecem a produção da sociedade, de tal modo que a universalidade do nominalismo anula a violência do acontecimento 20 . É verdade que a linguagem dos linguistas, por decisão epistemológica, é pura, a sua teoria elabora-se fora do conceito de comunicabilidade ou de referência ao mundo. Que não há referência senão no discurso, é uma tese comum a Ricoeur, a Coquet, a Culioli ou até a Wittgenstein, para quem a significação de uma palavra é o seu emprego dentro da linguagem. Que a semiótica isole o "sentido", da "referência», é uma opção que decorre dos seus próprios pressupostos teóricos. Com efeito, ao lado do postulado da sincronicidade, segundo o qual os sistemas são mais inteligíveis que as mudanças; e o postulado da formalidade, que quer que o sentido dum signo seja um valor diferencial num conjunto de entidades discretas, e que o sentido das sequências sintagmáticas resulte das capacidades combinatórias e algébricas de tais conjuntos, o postulado da imanência diz que todas as relações entre significados são internas aos sistemas semióticos, que sāo fechados, sem relações com uma realidade exterior não semiótica. Estes pressupostos constituem uma axiomática que instalará o paradigma da diferença e, por arrastamento, o processo da significância que elimina, por decisão epistemológica, a presença das coisas. $O$ objecto da semiótica restringe-se à descrição das formas internas da significação do texto, ou ainda às arti-

17 François Laruelle, La philosophie de la non philosophie, Pierre Mardaga, 1989, p. 47.

18 Cf. Cours, p. 43.

19 Ibidem, p. 166.

20 Jeudy, Les ruses de la communication, Paris, Plon, 1989, p. 164. 
culações constitutivas do micro-universo semântico. A crença num referente exterior confina com o preconceito pré-científico que, evidentemente, a semiótica recusa.

Quanto à linguística, não é menor a sua recusa de integrar o mundo nas suas análises: «seria um erro confundir referente externo e valor referencial, pois seria negar assim a relativa autonomia do funcionamento das línguas a respeito do mundo" 21 . Trata-se da reivindicação da autonomia do acontecimento linguístico construído/reconstruído em relação ao universo de estados de coisas. Podia dizer-se de outro modo: a referência construída pela actividade da linguística diz respeito, não ao «mundo real», mas ao "mundo projectado", isto é, construído pela experiência do falanteouvinte ${ }^{22}$. Mas aqui começa a dificuldade com os semânticos, para quem a teoria da referência está no coração do processo da significância. Pensar a linguagem não será pensar a unidade daquilo que Saussure separou, a unidade da língua e da fala? ${ }^{23}$ A recusa de abordar o sentido de maneira imanente caracteriza o estruturalismo de Brondal, que se inspira da Escola de Praga. O conceito de objecto, assim como a concepção anti-imanente fundamental e sistemática promanam explicitamente do conceito de intencionalidade que, se em Husserl é lógico e anti-psicológico, em Brondal reveste uma coloração psicologizante. Contemporâneo de Hjelmslev, Brondal partilha uma concepção assaz diferente do primeiro, que não acredita numa "brancura da linguagem», mas acredita que na sua origem está a interjeição. A Brondal ficará ligado um estruturalismo transcendental, sintético e reconstrutor, enquanto a Hjelmslev ficará ligado um estruturalismo imanente, analítico, empírico - dedutivo, separados por uma controvérsia epistemológica e uma ontologia 24.

O conceito linguístico de imanência formula-o Hjelmslev a partir de um princípio saussuriano, num contexto estruturalista, como é sabido. Este conceito será transferido em semiótica para as produções do sentido: a construção da significação, que é o objecto da semiótica, lê-se como um processo interno. Não é que o Sujeito seja então ignorado, mas metodologicamente, pelo menos, ele é excluído da análise das produçōes discursivas. Data dos anos setenta a reacção a esta exclusão. Cl. Calame cita a voz de J. Cl. Coquet: " $\mathrm{O}$ «eu» do sujeito (individual) não é o mesmo que o «Eu» do seu discurso» 25. Mas de facto a reacção tomou forma nos últimos

21 Culioli e Desclès 1981, pp. 19-20; ver Culioli 1985 b, p. 82.

22 Cf. Ray S. Jackendoff, Semantics and Cognition, Cambridge, MIT Press, p. 23ss.

23 S6 filosoficamente separamos a alma e o corpo, a "palavra operante» e a "palavra falante" que se incarna no meu corpo.

24 Cf. Langages, n. ${ }^{\circ} 86$, p. 79 ss. Vd. La quête du sens, Paris, PUF, 1997.

25 Ver Cruzeiro Semiotico, n. ${ }^{\circ}$ 5, Julho 1986, p. 9. 
anos, vinda de vários horizontes, não apenas semióticos. P. Bourdieu, por exemplo, critica a posição «imanentista» de Chomsky nestes termos: "Ao excluir qualquer relação entre as funções das expressões linguísticas e as suas propriedades estruturais, privilegiando as propriedades formais da gramática em detrimento dos constrangimentos funcionais, a estrutura relativamente ao uso, a coerência interna do discurso..., quer dizer nesta lógica puramente formalista «não gramatical», em detrimento da adaptação à situação, que, quando falta, pode lançar no absurdo os discursos mais coerentes, Chomsky sucumbe à ilusão eterna do gramático que esquece que a língua é feita para ser falada, que não há discurso senão para alguém e numa situação» 26 .

\section{Imanentismo, solipsismo}

O mal que reina na hermenêutica ou nas ciências humanas em geral vem, a meu ver, de uma koiné cujo denominador comum é a recusa de um "pensamento do compacto» - aquele que os homens da época metafísica definiram. A descontrução do sentido é a derrocada da ontologia e da teologia que está ligada àquela. $\mathrm{O}$ arbitrário do significante marca a abolição do metafísico e do teológico, do primado do Logos, do privilégio da palavra. A teoria do signo em Blanchot, por exemplo, funda-se na ausência. É uma teoria fundamentalmente sujeita à teologia hegeliana da linguagem, com uma série de metáforas em cadeia: a escrita como crime, morte. Tem razão Meschonnic que diz do modelo do signo na sociedade ocidental que ele é teológico-semiótico-político e greco-cristão ${ }^{27}$. O pensamento derridiano expande-se, no seu conjunto, a partir desta paisagem.

O signo pode definir-se simultaneamente em relação às trocas performadas entre os sujeitos e a um nível imanente, a título de inscrição topológica. Uma semiótica que tome em conta a intencionalidade do sentido distingue-se em muito de uma outra para a qual o sentido é um dado. $\mathrm{Na}$ abordagem formal, nominalista, do sentido, da tradição saussuriana, o sentido é um dado - em que as diferenças entre significantes devem explicar as diferenças entre significados, não havendo nenhuma maneira de ver de que forma se trata o significado. Mesmo se Hjelmslev falou de forma de significado e desenvolveu a ideia de forma do conteúdo que é a única forma transponível através da projecção do significante no significado. A forma do dado é uma estrutura com três actantes: Destinador, Desti-

26 Cf. Pierre Bourdieu, com Luc Boltanski, "Le fétichisme de la langue et l'illusion du communisme linguistiquen, Actes de la recherche en sciences sociales 4, julho 1975, p. 23.

27 Ver H. Meschonnic, Les états de la poétique, Paris, PUF, 1985, p. 28. 
natário, Objecto. $O$ conceito de forma altera-se completamente quando se trabalha a partir do sentido como intencionalidade. Mas vejamos como se perspectiva o signo, conforme o ponto de mira é a imanência ou a inscrição topológica.

No modelo da imanência vê-se invariavelmente surgir a inscrição dos significantes no espaço externo, enquanto o significado é inseparável do espaço interno. $\mathrm{O}$ espaço interno dá- nos a imagem dos estados de coisas, e o espaço externo dá-nos imagens das variações/deformações possíveis deste estado de coisas. A maneira como nós significamos as coisas depende da sua inscrição nas topologias - é isso o signo imanente, que nos permite substituir um significante por um outro, em vista de um significado. $O$ nível de manifestação do signo fornece-nos um cenário de dois sujeitos: há um significante e um significado porque há uma instância de interpretação entre os sujeitos. Se faço algo, há um outro que surge como sujeito cognitivo, a dizer: "o que fazes significa isto ou aquilo». Há, então, a este nível, um efeito de desdobramento, isto é, a interpretação existe, fundada na definição do significado relativamente ao interpretante. Há sentido quando algo circula, de modo que após uma interpretação, esse algo muda de estatuto: a interpretação agiu, transformou, deformou a coisa. Quando um objecto se encontra antes da interpretação, ele é interpretável, significante, num certo sentido; após a interpretação, ele é interpretado e significado. Um exemplo, o da troca das mulheres, no casamento em Africa, que o antropólogo Pradel de la Tour estudou:

1) Objecto (prestes) para a interpretação: é uma mulher - um ser humano apresentando um feno-físico mais ou menos inicial.

2) Após a interpretação, torna-se num objecto ritual de casamento objecto fonte de fruição infinita.

Assistimos a uma troca entre os sujeitos, neste caso, certo objecto conduz a outro em sentido inverso, sendo este objecto infinito (como significante). A emissão, a recepção e a interpretação do objecto indicam o regresso de um contra-objecto/interpretável.

As tradições linguísticas modernas recusam trabalhar com dados irredutivelmente externos. O solipsismo metodológico é a sua maneira de afirmar esta recusa. De Saussure a Hjelmslev e Greimas, o princípio da imanência mantém-se como a base da sua axiomática. Como sair do imanentismo? Como sair da poética estrutural, que é de uma grande negatividade, sem primado do sujeito, sem a expressão dum sentido real anterior, linguagem da escrita mais do que da fala, discreta, ausente das coisas? 
Como sair do eufeudamento à linguagem, do ensimesmamento? Se há um discurso particular que podemos chamar «literário», a sua especificidade não pode estar limitada à relação que ele estabelece com as palavras, formas da linguagem ou com os signos em geral, sim na relação que estabelece entre um sujeito e o mundo, por meio de formas e de conteúdos em parte convencionais. Como sair do paradigma da diferença e do específico do medium que é a escrita? Como passar ao discurso em língua natural? Como passar da escrita à oralidade? Escrevendo como se falasse.

Como pode uma ciência que toma a língua por objecto, como pode essa ciência esgotar ou mesmo tratar o valor mediador entre o homem e o mundo? Não é o sujeito vivo, essa pressuposição extra-linguística da enunciação, em relação de face a face dialogal,não é esse sujeito reduzido à sua inscrição no discurso? Como pode a linguagem funcionar como intermediário que leve ao real?

Ficam aqui duas propostas:

a) fundar na imanência uma relação com a realidade (Husserl, Searle, Brondal e Coquet esperam que a irrupção da matéria se instale no coração do dispositivo linguístico)

b) introduzir nas teorias da significação uma relação com estruturas irredutivelmente externas (é o que pretende Petitot com a sua teoria duma ontologia qualitativa, ou a inteligência artificial).

O conflito situa-se entre aqueles que sustentam que um fosso separa o real e a sua inscrição na língua - o que falta à linguagem é o real, dizia Benveniste - e aqueles que sustentam que a matéria se exprime morfologicamente e o regresso a um vitalismo substancialista. Ilustremos o problema a partir da querela estabelecida entre as «duas semióticas». A semiótica (primeira geração) é uma teoria conceptual com vocação descritiva. A Sémantique structurale participa do ponto de vista estruturalista geral de tipo formalista sobre a estrutura, em que se procura algo num nível de objectividade. Ser «estruturalista» é estabelecer esquemas coerentes a partir de constantes, de articulações localizadas no texto. Ao fazê-lo, imitar os criadores deste texto. Trabalho de «bricolage» (racional, coerente). $\mathrm{O}$ seu imperativo metodológico e epistemológico é restringir-se à forma e deixar de lado o resto. Foi-se muito longe, ao nível das abordagens descritivas. O estruturalismo continua a ser a maior das teorias das Ciências Humanas do século. Além das Ciências Cognitivas actuais, não há outra grande abordagem racionalista. Jakobson, Hjelmslev, Lévi-Strauss e Greimas são todos eles grandes cientistas que tentaram compreender um certo número de problemas e o problema principal que dá pelo nome 
de estrutura (é já a velha questão metafísica da relação entre o todo e as partes) 28 .

Paralelamente a esta perspectiva, visa-se alicerçar as estruturas abstractas em outros tipos de estrutura (v.g. as estruturas perceptivas) para dar conta da relação entre a estrutura e o mundo. Por outras palavras, alicerçar estas estruturas formais num certo tipo de realidade, começando por tomar em consideração os actos de linguagem. O que regressa agora é a teoria dos actos, uma semântica do ilocutório. A essa consciência correlativa das estruturas chama-se instância (da enunciação, do discurso). A subjectividade passa para primeiro plano como instância produtora de estruturas. Pensar o cultural intrínseco das estruturas, eis o projecto. A hipótese de que a semiótica seria uma teoria de códigos sociais em que a subjectividade seria apenas a assumpção progressiva do social que se interiorizaria, como a linguagem. Ora a questão é exactamente o contrário: nas interacções textuais há constantemente instâncias que transformam o nível discursivo e redefinem as condições de categorização da subjectividade. A questão da recategorização dos sujeitos, da sua transformação em subjectividade, é tão importante como a necessidade da ligação entre o esquema linguístico (a norma) e o uso (a fala).

Ficava o problema da semiótica fundamental que transforma o corpus teórico e as suas aplicações. Uma vez mais, a autonomia metodológica não é autonomia gnoseológica. Disso se ocupa presentemente a semiótica de segunda geração. Manter estas duas correntes, algebrista e geométrica, que produzem análises pertinentes; problematizar e avaliar têm sido as apostas que respectivamente que J. Petitot e J. Fontanille mantêm de pé.

A hipótese localista de J. Petitot aparece como a mais forte fundação deste deslocamento da primeira para a segunda geração de semióticos. Fazer valer a noção de estruturalismo dinâmico, é esse o programa de investigação em curso. A aposta: apreender os fenómenos da linguagem de uma forma não puramente imanentista, mas voltar às próprias coisas onde o corpo próprio tem algo a jogar ${ }^{29}$. Sair do solipsismo metodológico é romper com o ciclo vicioso que aborda os fenómenos de linguagem dentro dum fenómeno de linguagem. Porque a linguagem não é apenas simulacro.

28 Problema da organização, da estruturação dos objectos complexos. As ontologias regionais que cada um criou para um campo da realidade originaram a definiçāo de conceitos que são constitutivos da objectividade desses campos. Há, contudo, um problema com a formalizaçäo: como passar dos conceitos fundamentais aos verdadeiros modelos que possam ter relação com a experiência. $\hat{E}$ desse ponto de vista que Thom e Petitot defendem a necessidade de construir bons modelos matemáticos.

29 Vd. José Augusto Mourão, A semiótica na viragem morfodinamica (Lição de Agregação proferida a 20 de Outubro de 1999). 
Pode-se falar de presença vs existência semiótica. Pode-se falar de predicados de realidade e de correlato objectivo. Pode-se falar do tempo presente como centro gerador e axial, falando do devir ligado ao tempo presente. Em vez de um espaço estável, uma morfologia instável, deformável; em vez das modalidades definidas pela sua posição taxonómica (etiquetas numa combinatória), a hipótese do «todo modal» ou do «travejamento modal» do sentido. Introduzir a noção de contínuo, como um processo que age do interior do real e com ele. J. Cl. Coquet, por seu lado, num importante texto de questionamento do que ele chama a semiótica do enunciado, fundada por A. J. Greimas nos anos sessenta, tenta integrar as noções de predicação e de asserção, as instâncias, centros de discursividade, a história transformacional dos actantes, a relação realidade-verdade ${ }^{30}$. Se não podemos observar completamente um eclipse do sol, como lembra Sócrates no Fédon, podemos observar a sua projecção na água. A projecção não é a coisa, sim o seu correlato objectivo. Valendo-se de G. Frege, Coquet conclui: «o objecto de observação, digamos o eclipse (Bedeutung), é mais do que a sua «imagem real», a projecção (Sinn)» 31 . O acto de linguagem não tem lugar num universo de relações formais. Nem a predicação nem a asserção são aí estudados. Retomando o conceito de predicação, o nosso autor pode tratar do acto de linguagem e do Eu como centro de discursividade - pontos estratégicos do que ele chama semiótica subjectal.

\section{O solipsismo}

Mas o que é afinal o solipsismo? O solipsismo é o discurso paradoxal do «como se» de Kant. Exemplo de comportamento paradoxal: o escritor místico descreve a sua saída da ordem da linguagem e a sua contemplação não verbal de Deus, permanecendo dentro dos limites da linguagem. No sonambulismo podemos ter um comportamento como se estivéssemos acordados. O transe, o delírio, são fenómenos do mesmo tipo. O paradoxo provém do facto de haver fusão parcial e contradição entre dois níveis de verdade e de linguagem: o nivel $G$ relativo a uma generalidade (tudo o que diz Epiménides é mentira) e o nivel $\mathrm{P}$ relativo a um elemento particular e singular desta generalidade (a frase particular, através da qual Epiménides diz que tudo-o-que-ele diz- é mentira, é verdadeira). Num enunciado paradoxal, o que se encontra justificado a um nível $\mathrm{P}$ encontramo-lo incluído num sistema $G$ de coordenadas epistémicas mais vastas que inclui

30 Cf. J. Cl. Coquet, «Lêtre et le passage ou d'une sémiotique à l'autre» in TLE, 1988, Presses Universitaires de Vincennes: 91-112.

31 Ibidem: 105. 
o primeiro nível 32. O paradoxo vem de que $G$, ao incluir $P$, contradiz $P$. O paradoxo consiste então em querer, dentro dum nível epistémico $\mathrm{n}$, dar conta duma verdade de uma ordem m (incompatível com $n$ ) ou de uma ordem $n+1$ englobante e mais forte que o nível $n$. $O$ «como se»de Kant consiste em fazer como se eu pudesse sair do nível epistémico em que me encontro (o de uma visão perspectivista sobre o mundo) para me situar no plano epistémico relativo à enunciação de uma verdade objectiva ou global sobre o mundo (isto é, um nível superior ao precedente). Paradoxal é querer, através duma linguagem (n) dar conta do silêncio (m). Um discurso que quer pensar a totalidade, situando-se no interior desta totalidade, torna-se paradoxal. O discurso "como se» é um discurso que, sabendo embora, e confessando-o, que se situa a um nível epistémico $n$, se edifica como se pudesse situar-se ao nível epistémico $n+1$, o único apto a resolver as aporias encontradas no nível $\mathrm{n}$, e a fundar o conhecimento de nível $\mathrm{n}$. Será assim o discurso teológico, e não só, como veremos 33 .

Na semiótica do mundo natural, visa-se uma exterioridade como referente, mas esta exterioridade define-se em termos daquilo de que ela é referente. Daí o solipsismo. A percepção mima as estruturas reais do mundo. $\mathrm{Na}$ relação da linguagem/mundo, os enunciados funcionam à «semelhança» dos estados de coisas. Com que estrutura? Como descrevê-los? De modo não linguístico? A semiótica de segunda geração reconhece a impossibilidade de descrever de maneira não-perceptiva, linguística, semiótica, etc., o que é significativo (pertinente) no mundo exterior pela percepção da linguagem, da semiótica, etc. O solipsismo é metodológico - é mesmo esse o requisito para autonomizar o objecto - mas não deixa de pôr problemas epistemológicos consideráveis. As consequências: todas as descrições são formais; nada se pode dizer sobre os conteúdos; formaliza-se a forma. A mesma semiótica postula que é impossível definir rigorosamente uma ontologia qualitativa à maneira de Aristóteles. O mundo sensível (do sentido comum) desapareceu como conceito ontológico quando se lançou a hipótese de que a Física objectiva (que a ruptura galileana instaura) esgota o conteúdo da realidade externa como autónoma (independente de nós). O que assim se afastava era o fenomenológico (que releva do sujeito: constituição subjectiva) e a teoria da intencionalidade que afirma uma relação constitutiva com o mundo exterior. A tese de J. Petitot, que se inscreve na tradição aristotélica ressurgida (Thom ou o cognitivismo contemporâneo de Tulmy e Jackendorff), intervém aqui, afirmando que há estruturas perti-

32 Cite-se, a este propósito, Jean François Lyotard, Le différend, Paris, Minuit, 1983.

33 Cf. Alain Houziaux, "L'Ébranlement des Fondements de la Science et de la Théologie» in : RSPT 73 (1989) 205-232. 
nentes, há formas e qualidades (para a linguagem) autónomas (independentes de nós).

\section{Sair do solipsismo?}

Como sair do solipsismo metodológico? É verdade que o único conteúdo autónomo do mundo é fisicalista? Não haverá estruturas emergentes, autónomas? Haverá lugar para uma ontologia qualitativa?

Para J. Petitot. o mundo projectado é um correlato objectivo para a linguagem. Este mundo é projectado pela estrutura conceptual. O mundo qualitativo, correlato da linguagem, não é linguístico nem semiótico. O espaço externo de representação não é físico, procede de uma projecção. Os actos mentais representam o exterior a partir do físico subjacente. Reconhece-se então uma interface entre o mundo real e a estrutura conceptual, uma relação interactiva 34 .

É necessário ultrapassar um pressuposto constante ainda no pensamento ocidental desde Santo Agostinho: a pressuposição do solipsismo metódico que Husserl foi o último a defender ${ }^{35}$. O. Apel propõe um esquema que desenvolve o da relação triádica do signo peirciano, incorporando este a teoria dos actos da linguagem, isto é, acentuando a dupla estrutura performativo-proposicional dos actos locutórios e dos enunciados que os exprimem explicitamente. Na base desta teoria, a nível semântico, estão as funções proposicionais, que comunicam com as funçōes performativas, a nível pragmático, implicando simultaneamente a presença de um sujeito e de um co-sujeito, nas atitudes comunicativas. O ponto de vista de Apel exprime uma concepção pragmático-integrativa da semiótica, tendo em conta a triadicidade do princípio de relação do signo peirciano. Propondo a transformação pragmático transcendental da função sujeito do conhecimento, mediatizada semioticamente como função do intérprete do signo, que integre a priori a transformação semântica transcendental, Apel pretende ultrapassar o "solipsismo metódico» da filosofia transcendental clássica, que negligencia a distinção das significações semióticas da linguagem como condição da possibilidade da validade intersubjectiva do sentido ${ }^{36}$.

34 Ver Jean Petitot, "Le tournant morphologique» in Actas do Colóquio de Toulouse $13 \mathrm{e}$ 14 XII 1989 sobre a Expressão: 91- 107; «La lacune du contour», Lisboa, Analise, 1 (1),101-140; ver também R. Jackendoff, Semantics and Cognition, MIT Press, Cambridge, 1983; Consciousness and Computational Mind, MIT Press, Cambridge, 1983.

35 Cf. Apel, in Cruzeiro semiótico, n. ${ }^{\circ} 8$, Janeiro de 1988, p. 31.

36 Ibidem: 40. 
O solipsismo participa do erro que consiste na pretensão de exprimir algo sobre o mundo de um ponto de vista exterior ao mundo no qual nos encontramos. O solipsismo metafísico é vítima ilustre deste erro, dado que o solipsista é alguém que pretende que a linguagem apenas pode remeter para o seu universo pessoal de representaçōes e ideias, mas que é obrigado a sair dos limites da linguagem assim concebida e de a considerar do exterior, para poder afirmar isso. $O$ solipsista metodológico pensa que toda a justificação se faz em termos da experiência de que cada um tem um conhecimento privado. Por isso diz: «só eu existo, tudo o resto é produto da imaginação, uma alucinação.» Esta é a forma mais extrema do subjectivismo, afirmar que apenas podemos conhecer a nossa consciência ou que fora dela nada existe. Universo e estado mental identificam-se ${ }^{37}$.

Recusa-se o ideal cientista do sentido total, não a sedução duma plenitude imaginária, o charme discreto da parte fractal, viral, o inexprimível da linguagem privada: Individuum est ineffabile. Gadamer dizia que o que existe não pode ser compreendido na sua totalidade. O resto é indizível, como Genet escreve: «Resto diz-se sempre da mãe». Segundo Wittgenstein, o que o solipsista quer dizer não pode ser expresso, apenas mostrado. A ilusão angélica consiste em pensar que se pode ter simultaneamente um pé fora e um pé dentro da linguagem - falar da possibilidade de descrição, de que a linguagem estaria por natureza privada. Impossível considerar ao mesmo tempo o espelho e o que ele reflecte, e julgar da «fidelidade» do primeiro, confrontando, qualquer que seja o modo, a imagem com o objecto. $\mathrm{O}$ misticismo tradicional funda-se implicitamente na ideia de que falta sempre dizer algo quando a linguagem já disse tudo o que podia. Implicando isto que se possa falar pelo menos uma vez da realidade sem passar pela linguagem, para dizer que a linguagem não permite esgotar a realidade ou que deixa de lado algo essencial. Como é sabido, o elemento essencial do "misticismo» de Wittgenstein é a impossibilidade da metalinguagem: não nos podemos colocar fora dos limites da linguagem e do mundo. É a impossibilidade de uma proposição falar de outra proposição, impossibilidade de formular o que quer que seja sobre a essência da linguagem. A proposição 6.522 indica claramente que, no espírito de Wittgenstein, a expressão: «das Mystische» corresponde ao termo mais ou menos convencional que serve de designaçāo global para tudo o que não pode ser expresso, apenas manifestado. Místico evoca uma região não vazia exterior à linguagem ${ }^{38}$. O que Wittgenstein nega é que possamos, através da linguagem, romper momentaneamente com a conexão necessária que

37 Veja-e, por exemplo, Lynn Segal, Le Rêve de la Réalité, Paris, Seuil, 1990.

38 Cf. Jacques Bouveresse, Wittgenstein:La Rime et la Raison. Science, Ethique et Esthetique, Paris, Minuit, 1973. 
existe entre os seus elementos e os da realidade para confrontar globalmente os recursos de uma com a outra, o que a linguagem pode dizer com o que há a dizer. $O$ Tratactus proíbe-nos definitivamente qualquer tentativa para julgar a linguagem deste ponto de vista (C, p. 196).

Abordagem paradoxal esta, que pretende coadunar a imanência, a materialidade do objecto (textual), suspendendo o discurso e o sujeito, para falar precisamente do sujeito e do discurso. Impossibilidade de descrever de maneira não perceptiva, linguística, semiótica, etc., o que é significativo (pertinente) no mundo exterior, pela percepção da linguagem, da semiótica, etc. Aí está o círculo - o que é pertinente para X é a projecção das estruturas sobre a realidade exterior. Circularidade entre a teoria da referência e do sistema simbólico, afinal esta exterioridade é uma interioridade do sistema. A moral provisória é a de que não há meio de fazer de outro modo: "O solipsismo não é nem uma aberração nem um sofisma, mas a própria estrutura da razão» (E. Levinas).

\section{O arbitrário necessário}

A ciência tradicional é prisioneira do paradigma da simplificação (redução e disjunção) ${ }^{39}$. O paradigma da ciência moderna exclui a reciprocidade de conhecimento que se estabelece quando comunicamos uns com os outros. Boaventura Sousa Santos parte da distinção entre compreender/explicar para tentar, a partir dela, tirar novas conclusões: Para mim, compreender é a possibilidade de eu estar dentro do outro. Fazer com que a relação sujeito/objecto seja cada vez mais substituída por uma relação eu/tu é tarefa da compreensão 40 . Trata-se sempre de produzir conhecimento intersubjectivo no quadro de teorias e de métodos explicitados e intersubjectivamente aceites. Sendo a enunciação da ciência mostrativa, o universo referencial dos textos científicos supõe estruturas sémio-linguísticas que definem uma imagem perceptível relativamente, quer a um real fenomenal, quer a sujeitos cognitivos. Ao lado duma abordagem que reduz a linguagem da ciência a uma sintaxe lógica de termos observacionais e de uma outra que a transforma num dicionário de vocabulário técnico, é necessário interessar-se à ancoragem do discurso na experiência fenomenógica do sujeito, evitando o reducionismo sociológico.

39 John W. Dawson, "Godel and the Limits of Logic", in Scientific American, June 1999, p. 68.

40 Cf. $J L, 25.5 .89$; ver deste autor, Um Discurso sobre as Ciências, Lisboa, Afrontamento, 1987; Introdução a uma Ciência pos-moderna, Lisboa, Afrontamento, 1989. 
"La recherche scientifique est réductrice ou ellle n'est rien», escreve R. Girard ${ }^{41}$. A ciência procede por delimitação do campo (da ciência às ciências), pela definição de princípios, de métodos e de procedimentos, por capacidade de instrumentação (mental e instrumental). A ciência moderna nasce de duas rupturas - por redução - com a Natureza e com o homem. De Copérnico a Laplace e passando por Newton. Kant irá teorizar este esforço: só há ciência do fenómeno e do verificável pela experiência nos limites da razão. O Noumenon não é ainda para ele "o inconhecível» evanescente de Spencer, mas o domínio reservado da fé e da ética. A condição de possibilidade da ciência passa pelo princípio de redução que ele postula à partida da sua construção e cuja legitimidade se demonstra pela sua fecundidade, portanto a posteriori. $\mathrm{O}$ reducionismo permitiu à ciência constituir-se e progredir. Discretizar é dar passos. O quadrado semiótico, por exemplo, é um desses instrumentos de redução à sua relação mínima. É uma combinatória que permite visualizar as polaridades em torno das quais se constitui a estrutura elementar da significação de um texto. Que fiquem restos desta redução, não invalida o poder heurístico do quadrado. Fazer do resto a definição da Literatura, é recusar-se a considerá-la como um todo autónomo, articulado como qualquer outro tipo de discurso, segundo as leis próprias da significância, ou como um objecto de conhecimento.

A resistência ao reducionismo pode formular-se assim: será que tudo se pode descrever em língua matemática? Se o reducionismo se torna a regra comum do pensamento e da crença, não cairemos na desumanização absoluta? Reduzem-se as qualidades sensíveis a simples propriedades do objecto? Não será a ciência "holista», sintética, mais desejável? E o conhecimento a que só se chega pelas vias do esoterismo, o irracional, a abdução, a iniciação secreta? 42

O reducionismo é contestável se se tornou, não um método discutível, mas uma pretensão de explicação totalizante e exclusiva da realidade. Mas basta não confundir limitação com redução e reducionismo. A limitação do campo de investigação é uma etapa necessária e sã do exercício científico. Evitar o reducionismo é evitar a ideia de que as unidades que compõem um todo sāo ontologicamente primeiras em relação a este todo. A análise fisioquímica (do papel e da tinta) e geométrica da escrita nada ensina dos motivos que fizeram enviar a mensagem (a sua causalidade), do seu conteúdo (a sua semântica) e do que se espera do seu destinatário (a sua

41 René Girard, Des choses cachées depuis la fondation du monde, Paris, Grasser, 1978, p. 48.

42 Ver J. Monod, Le hasard et la nécessite, Paris, Seuil, 1970; F. Jacob, La logique du vivant. Une histoire de l'herédite, Paris, Gallimard, 1970; J.P. Changeux, L homme neuronal, Paris, Fayard, 1983. 
finalidade). De resto, teremos sempre «o coro das carpideiras do humano acompanhando a verificação das devastações produzidas pela temível lepra das formalizações» 43 . Claro que não se pode pedir à semiótica o mesmo nível de redução que consegue a física, quanto mais não fosse pelo lado da sua confessada contaminação fenomenológica. O objecto do programa de investigação semiótico não é o mesmo que o do historiador da literatura, por exemplo ${ }^{44}$. As descrições de Popper só parecem válidas para as ciências exactas, capazes de prever experiências que eventualmente falsificarão a «conjectura» proposta.

Afinal, que isso nos agrade ou não, o arbitrário está no princípio de todos os campos, mesmo os mais "puros», como os mundos artístico ou científico: cada um deles tem a sua «lei fundamental», o seu nomos 45 . Morin (1983) considera que a atitude científica tradicional obriga a uma leitura apenas determinista, leitura que exclui toda a ideia de autonomia e de individualidade, excluindo no mesmo lance o sujeito e com ele a ideia de recursividade organizacional e a liberdade como propriedade daí emergente. A problemática «intencional» e «tensiva» entrou na semiótica para quebrar o tropeço que constituia o imanentismo fechado, via fenomenologia, e ciências cognitivas. É aí que estamos hoje.

43 Cf. E. Prado Coelho. op. cit., p. 72.

44 Ver de M. Grimaud: «Prosopopée de sainte Sophie, patronnne des poéticiennes (Vers une science des textes)" in Poétique, 43, pp. 372-391; e "Préliminaires pour une Psycholinguistique des discours (Le champ de la Poétique) » in Langue Française 4 49, Fevereiro 1984, pp. $14-29$.

45 P. Bourdieu op. cit., p. 116. 